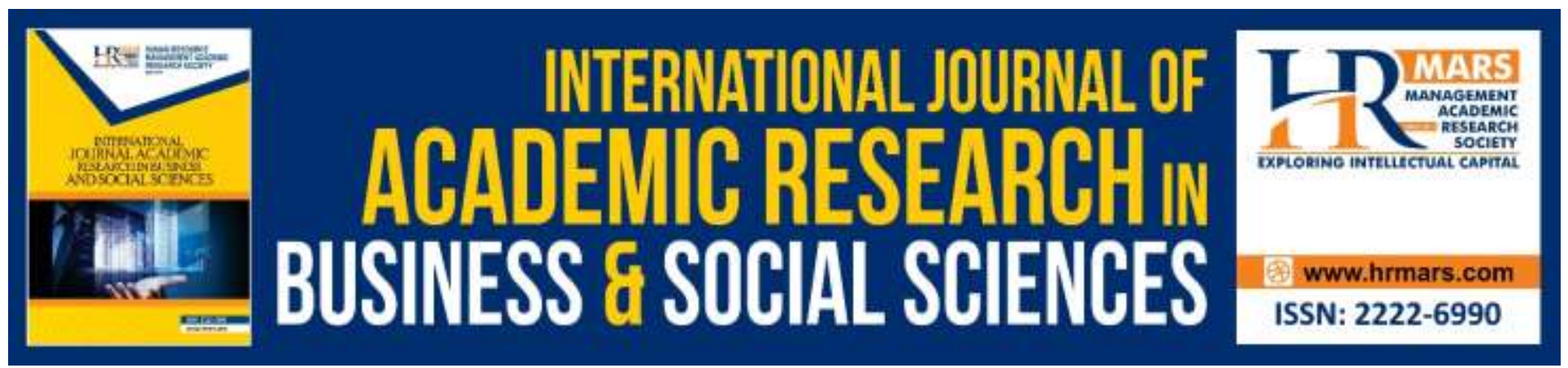

\title{
Learning Economics Concepts with Music Videos among Pre- service Teachers
}

\author{
Khoo Yin Yin, Rohaila Yusof, Nadiah Yan Abdullah
}

To Link this Article: http://dx.doi.org/10.6007/IJARBSS/v9-i7/6133

DOI: $10.6007 /$ IJARBSS/v9-i7/6133

Received: 20 May 2019, Revised: 20 June 2019, Accepted: 03 July 2019

Published Online: 26 July 2019

In-Text Citation: (Yin, Yusof, \& Abdullah, 2019)

To Cite this Article: Yin, K. Y., Yusof, R., \& Abdullah, N. Y. (2019). Learning Economics Concepts with Music Videos among Pre-service Teachers. International Journal of Academic Research in Business and Social Sciences, 9(7), 410-416.

\section{Copyright: (C) 2019 The Author(s)}

Published by Human Resource Management Academic Research Society (www.hrmars.com)

This article is published under the Creative Commons Attribution (CC BY 4.0) license. Anyone may reproduce, distribute, translate and create derivative works of this article (for both commercial and non-commercial purposes), subject to full attribution to the original publication and authors. The full terms of this license may be seen

at: http://creativecommons.org/licences/by/4.0/legalcode

Vol. 9, No. 7, 2019, Pg. 410 - 416

http://hrmars.com/index.php/pages/detail/IJARBSS

JOURNAL HOMEPAGE

Full Terms \& Conditions of access and use can be found at http://hrmars.com/index.php/pages/detail/publication-ethics 


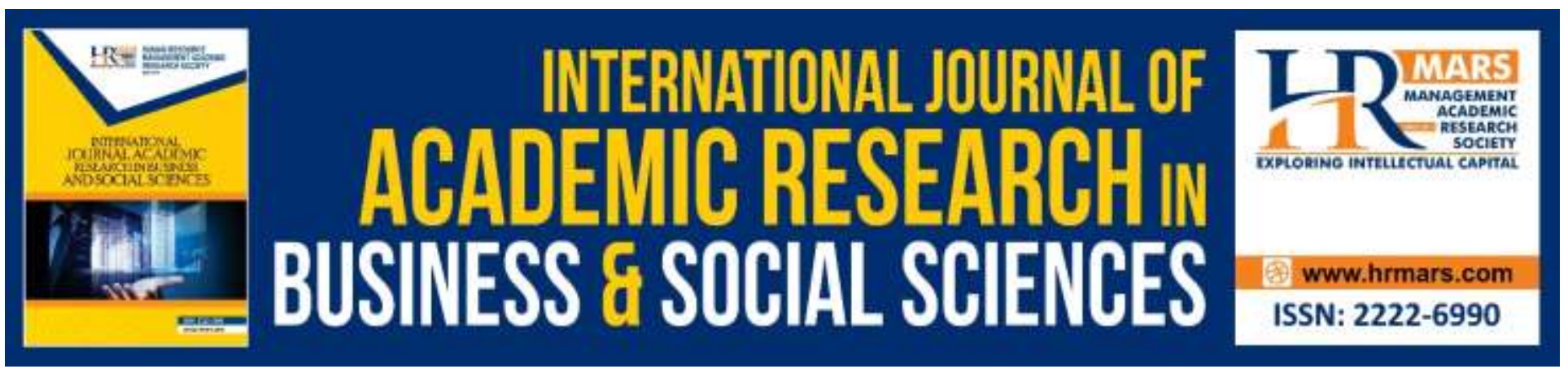

\title{
Learning Economics Concepts with Music Videos among Pre-service Teachers
}

\author{
Khoo Yin Yin, Rohaila Yusof, Nadiah Yan Abdullah \\ Universiti Pendidikan Sultan Idris
}

\begin{abstract}
The purpose of this paper was to foster the conceptual understanding through music videos among pre-service Economics teachers. Students' learning interest towards music video was also examined. A quantitative research method with descriptive survey design was employed in this study. A total of 90 pre-service teachers were employed as respondents. The findings indicated that music video contributes significant results towards students' performance, and interest. Further research will focus on qualitative research.
\end{abstract}

Keywords: Economics Concepts, Music Videos, Interview, Mobile Phone

\section{Introduction}

In the new era of technology advancement, a lot of people like to create their own digital videos, especially our young generation. In other words, students nowadays can create new videos, integrated with music, animation and emerging multimedia online environment (Alby, 2007 \& Zahn, et al. 2014). Since creating new videos has become a trend, teachers have to develop videos and employ them as teaching aids in the lesson. Students today are more tech savy and almost all of them own some digital tools such as smartphones, tablets and laptops.

Music is a universal language and most of us like it. In the $21^{\text {st }}$ century, music is always integrated with technology and widely delivered (Marsh, 2010; Acker \& Nyland, 2015), for instance, music videos. In order to align with Education 4.0, students' creative and innovative thinking has always become a priority. Education 4.0 emphasises that students can learn by doing, they can create and share (Almeida \& Simoes, 2019). On the other hand, Economics is an elective subject in the upper secondary school. It is always classified as a difficult subject and as a result, a number of students fail due to poor performance (Dos Reis \& Yu, 2018). Referring to Table 1, Malaysia Examination Council (2017) reported that there were 21,091 students who took Economics in semester 1, 2013/2014 but only 13,549 remained taking Economics in semester 3 . A similar situation happened in the year of $2014 / 2015$, there were 14,618 enrolled in the beginning but only 13,444 remained at the end of the semester 3. The Economics' candidates deteriorated in the year of 2015/2016 too, from 14,082 to 13,543 . Many students were unable to cope the subject, which has become the crucial factor of the 
INTERNATIONAL JOURNAL OF ACADEMIC RESEARCH IN BUSINESS AND SOCIAL SCIENCES Vol. 9, No. 7, July, 2019, E-ISSN: 2222-6990 @ 2019 HRMARS

mentioned phenomena. A similar situation happened in university, especially those pre-service teachers that did not study Economics in high school. They were weak in understanding the Economics concepts, some of their results were below average.

Table 1: Pre-University Economics Students' Enrolment

\begin{tabular}{cccccc}
\hline Enrolment & $\begin{array}{c}\text { Semester 1 } \\
\text { (students) }\end{array}$ & $\begin{array}{c}\% \\
(+/-)\end{array}$ & $\begin{array}{c}\text { Semester 2 } \\
\text { (students) }\end{array}$ & $\begin{array}{c}\text { Semester 3 } \\
\text { (students) }\end{array}$ & \% Drop \\
\hline $2013 / 14$ & 21.091 & & 14,077 & 13,549 & $35.76 \%$ \\
$2014 / 15$ & 14,618 & -30.69 & 13,745 & 13,444 & $8.03 \%$ \\
$2015 / 16$ & 14.082 & -3.67 & 13,761 & 13,543 & $3.83 \%$ \\
\hline
\end{tabular}

Source: Malaysia Examination Council (2017)

Therefore, the pre-service teachers need to be instilled with the skill of developing music videos in order to contribute to their future students. The purpose of this study was to foster the conceptual understanding of Economics' concepts through music videos among pre-service Economics teachers. Students' learning interest towards the music video was also explored in this study.

\section{Literature Review}

Two subtopics are discussed in this part, conceptual understanding in teaching and learning Economics and conceptual understanding based on the Gagne Theory.

\section{Conceptual Understanding in Teaching and Learning Economics}

In understanding Economics' concepts, students need to evaluate some of the elements in different situations in order to relate to their prior knowledge. Some concepts are easy to understand while some complex concepts require deep understanding, and reasoning ability to master the concepts. A student who learns through memorization cannot comprehend the concepts in depth, especially complex concepts.

According to Chu Kin-Cheong and Patrick Lai (2002), good teaching practice can encourage deep learning especially when students have hands-on experience. Collaborative learning encourages students to share the ideas among peers and enhances conceptual understanding

Based on the above statement, the Economics sub-topics like demand, supply, elasticity of demand and elasticity of supply need to be taught through songs for promoting the conceptual understanding. Walstad (1996) and Yazici (2005) shared the same views, peer discussions in collaborative groups or hands-on activities are strongly recommended to help students understand the Economics concepts in depth. According to Sadovnik (2016), songs can make students understand concepts better. Songs can also help students to remember terms or vocabularies (Bahrami, Izadpanah \& Bijani, 2019).

\section{Gegne Theory}

Gagne (1977) said that the learning process occurs when the stimulus from the external environment is received into the nervous system, interpreted in the short-term memory and then transmitted to the long-term memory and to the actuator of the reaction through the nervous 
system. He added that the experience stored in the long-term memory store is associated with new experiences in order to facilitate the new learning process.

Gagne (1977) has identified five categories of learning from simple levels to complex levels; verbal information, intellectual skills, cognitive strategies, motor skills and attitudes. Verbal information includes facts and knowledge. This learning happens when students receive information related to verbal responses to facts or knowledge. Intellectual skills include discrimination, conceptual learning, principle learning and problem solving. Discrimination is that students produce different responses after learning. Conceptual learning refers to the ability of students to classify and explain abstract concepts. Two concepts that relate to learning are known as principle learning. Problem solving is a learning that involves thinking processes by applying the concepts and principles learned. However, only the conceptual understanding will be discussed in this section.

Conceptual understanding means constructing an idea from concrete examples. The concept can be represented by a symbol based on the same characteristics. A student can be said to have understood the concept of elasticity of demand when he is able to classify the characteristics of elastic or nonelastic demand. Students can learn and understand the concepts of Economics through deep learning.

Students can be classified as understanding the concepts when the concepts can be applied in daily activities. However, teachers need to develop innovative teaching and learning methods, for example, develop music videos in order to enhance students' conceptual understanding of Economics concepts.

\section{Methodology}

This study employed a quantitative research method with descriptive survey design. This design was selected because to meet the objectives of the research in term of the effectiveness of the learning method. It also provides an accurate portrayal or account of the characteristics of a group (Mathers, Fox \& Hunn, 2007). On the other hand, survey research can examine the correlations among the participants' responses for possible cause and effect. (McBurney \& White, 2007), for example, the researchers examined the relationship between students' performance and economics' foundation. Random sampling was selected according to the group basic in order not to interrupt the students' class schedule. There were 90 students who participated in this study. All the students were allowed to discuss their work in groups of four but they had to produce their music video individually. Students needed to submit a music video based on the lecturer's instruction.

After each topic, students needed to use the Economics concepts to produce the music videos. They were allowed to modified the melody of popular songs or create their own music. They could sing alone or get others' assistance.

The questions consisted of 30 close-ended achievement test. The test was used to measure the conceptual understanding of the pre-service teachers after developing the music videos. A set of 20 
INTERNATIONAL JOURNAL OF ACADEMIC RESEARCH IN BUSINESS AND SOCIAL SCIENCES

Vol. 9, No. 7, July, 2019, E-ISSN: 2222-6990 @ 2019 HRMARS

items questionnaire was administered in this study too. This questionnaire was employed to measure students' learning interest after developing the music video. The face validity and reliability of the questionnaire had been checked during the pilot test. The questionnaire has a reliability of Cronbach's Alpha .901.

\section{Findings}

Table 1 shows the students' performance in Economics' assessment after developing the music videos. Hypothesis testing was employed by inferential statistical analysis. One sample t-test was conducted to determine whether there is significant of students' performance after developing the music videos. The assumption of the t test is violated because the variance of the whole group of the students was met. The students obtained the mean score of 67.000 with standard deviation 20.26 and standard error 2.135. This finding was also significant with the t value of $31.369(p<.05)$. Thus, the null hypothesis was rejected.

Table 1: Mean Score for Performance Assessment in Economics

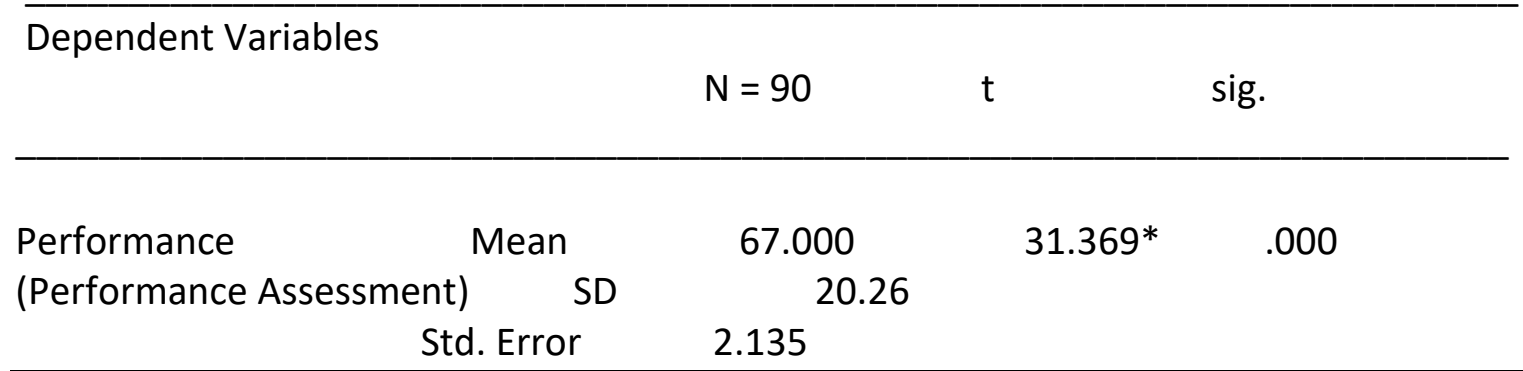

*significant at $<.05$

A further investigation was made to check the relationship between students' performance and their Economics' foundation. In other words, whether the students had been taken Economics during their pre-university.

Table 2 indicates the unstandardized regression coefficient $(B)$ for predicting Economics performance and Economics taken during pre-university is $B=.538,(p<.05), F=(1,88)=35.889, p<.001 ; r=.538$. The regression predicting Economics achievement from and Economics taken during high school is statistically significant. From the model $r^{2}=.29$ indicating $29 \%$ of the variance in the Economics performance is predicted by Economics taken during the high school. Since the relationship is positive, this means that taking Economics course during pre-university is associated with high performance. 
INTERNATIONAL JOURNAL OF ACADEMIC RESEARCH IN BUSINESS AND SOCIAL SCIENCES

Vol. 9, No. 7, July, 2019, E-ISSN: 2222-6990 @ 2019 HRMARS

Table 2: Model Summary and ANOVA for Economics Performance and Economics taken during Pre-University

\begin{tabular}{lccc}
\hline Predictor & $F$ & $r$ & r square \\
\hline Economics & $35.889^{*}$ & .538 & .29 \\
Performance & & & \\
\hline
\end{tabular}

*significant at $<.05$

Table 3 shows the students' learning interest after developing music videos. All the students answered the 20 items questionnaire. The results showed the high average mean score of 4.326 and standard deviation 1.52. "Learning materials in the music videos were colored, animated and interesting" indicated the highest mean score (Mean=3.96) among all the items. Hence, the majority of the students liked to learn with music videos.

Table 3: Mean Score for Students' Learning Interest

\begin{tabular}{lccc}
\hline Variable & $\mathrm{N}$ & Mean & SD \\
\hline Learning interest & 90 & 4.326 & 1.52 \\
\hline
\end{tabular}

\section{Discussion and Conclusion}

The music video has produced significant results on performance and students' learning interest. The students gained hand-on experience in developing music videos. They had to understand Economics concepts with "learning by doing". The students can only develop the lyrics after understanding the concepts thoroughly that we identify as deep learning. Researchers believe that deep learning can solve problem in language, audio and video (Kamaruzaman, Alhwaiti \& Tappert, 2019).

This study is important because it integrated music, technology, language and Economics concepts while students were developing the music videos. The music videos are capable to increase students' creative and innovative thinking besides fostering their conceptual understanding of Economics concepts. The hands-on learning activities allow the pre-service teachers to apply what they learned in a practical way. It also in line with Education 4.0 to benefit more students in future with more effective and interactive learning videos that "wow" the class. It can bring the positive effect in teaching if teachers choose or create good videos. However, pre-service teachers should be more careful in term of the content during developing videos because the quality of content brings influences the students. The moral values that instil in the content should be noticed, for instance, the value of saving should be instil in the topic of money. Students can only get the money through their hard work but not from the criminal.

Despite challenges and difficulties faced by the students while creating music videos, the students had spent weeks to complete them. The only limitation in this study is that all the participants were from one public university. It will be interesting if the participants come from a few different universities. This learning method can help higher learning institutions to transform new teaching 
INTERNATIONAL JOURNAL OF ACADEMIC RESEARCH IN BUSINESS AND SOCIAL SCIENCES

Vol. 9, No. 7, July, 2019, E-ISSN: 2222-6990 ¿ 2019 HRMARS

and learning method in the $21^{\text {st }}$ century. The future study may also focus more on qualitative research, for instance interviews with the students.

\section{Acknowledgement}

This research is funded by UPSI Innovative Teaching and Learning Research Grant (2018-0174-10701).

\section{References}

Almeida, F., \& Simoes, J. (2019). The role of series games, gamification and industry 4.0 tools in the education 4.0 paradigm. Contemporary Education Technology, 10(2), 120-136.

Alby, T. (2007). Web 2.0: Concepts, applications, technologies. Munich: Hanser Fachbuchverlag.

Acker, A., \& Nyland, B. (2015). The relationship between children's learning through music and the use of technology. Australia Journal of Music Education, 1, 64-74.

Bahrami, Z. N., Izadpanah, S., \& Bijani, H. (2019). The impact of musical mnemonic on vocabulary recalling of Iranian young learners. International Journal of Instruction, 12(1), 977994.

Kin-Cheong, C. \& Lai, P. (2002). How can engineering students' problem solving skills be improved? Hong Kong: Hong Kong Institute of Vocational Education \& Hong Kong Polytechnic University.

Gagne, R. M. (1977). The condition of learning. USA: Holt, Rinehart \& Winston.

Yazici, H. J. (2005). A study of collaborative learning style and team learning performance. University of Wiscousin-La Crosse.

Kamaruzzaman, A., Alhwaiti, Y., \& Tappert, C. C. (2019). Developing and deep learning model to implement Rosenblatt's experiential memory brain model. Advances in Information and Communication, 70, 248-261.

Marsh, J. (2010). Young children's play in virtual worlds. Journal of Early Childhood Research, 8(1), 23-29.

Mathers, N., Fox, N., \& Hunn, A. (2007). Surveys and questionnaires. The NIHR RDS for the East Midlands / Yorkshire \& the Humber, Nigel Mathers Academic.

McBurry, D. H. \& White, T. L. (2007). Research methods 7. USA: Thomson.

Sadovnik, N. (2016). Shira Chadasha: A new song for an old community. Music Therapy Perspective, 34(2), 147-153.

Walstad, W. B. (Ed.). (1996). Secondary Economics and Business Education. New Developments in the United Kingdom, United States and Other Nations, London: Economics and Business Education Association.

Zahn, C., Schaeffeler, N., Giel, K. E., Wessel, D., Thiel, A., Zipfel, S., \& Hesse, F. W. (2014). Video clips for YouTube: Collaborative video creation as an editorial concept for knowledge acquisition and attitude change related to obesity stigmatization. Education International Technology, 19, 603-621. 